International Journal of Application Computer Science and Informatic Engineering (ACSIE)

Vol.1, No.1, May 2019, pp. 11 20

ISSN (print): $\mathrm{xxxx}-\mathrm{xxxx}$, ISSN (online): $\mathrm{xxxx}-\mathrm{xxxx}$

DOI: https://doi.org/10.33173/acsie.35

\title{
Decision Support System for Restaurant Selection in Badung Regency with Geography Visualization
}

\author{
Brigida Arie Minartiningtyas ${ }^{1}$, I Made Bayu Prawira*2 \\ ${ }^{1,2}$ Jurusan Teknik Informatika, STMIK STIKOM Indonesia, Bali \\ e-mail: * ${ }^{1}$ brigida@stiki-indonesia.com, ${ }^{2}$ bayu.prawira@ stiki-indonesia.com
}

\begin{abstract}
Decision Support System (DSS) is a system that can assist a person in making accurate decisions and on target. Many problems can be solved by using the DSS, which one is the selection of restaurants in Badung Region. There are several methods that can be used in building a DSS include Weighted Product (WP). WP is a method that the most widely used in solving problems with multiple criteria, such as DSS for selection of restaurants in Badung Region.

This research uses the WP method for selection of restaurants in Badung Region. In determining the best choice of restaurants, there are several criterias that will use on taken the decisions, there are the quality of food, price, service, atmosphere, and distance. The value of each of these criteria derived from the reviews or ratings of other users, so these values are dynamic. User can freely set the value of the weight of each criterion to be compared in order to obtain the best results.

The end result of this research is built a system that can help users to compare several restaurants that the results will be sorted from the best based on the results of the comparison weight that has been entere.
\end{abstract}

Keywords—Decision Support System, Geographic Visualization, Weighted Product

\section{INTRODUCTION}

Bali is an area that is famous as a tourist destination in the world. This island, which is part of the country of Indonesia, has strong cultural customs and very strong religious nuances so it is very interesting to be visited by tourists. The development of tourism in Bali, which tends to increase, has an impact on Bali's rapid regional development, especially in the Badung Regency area.

Badung Regency is the gateway to the tourism sector for tourists who want to travel to Bali. Geographically, Badung Regency has a very strategic position, which is located next to the Denpasar region, Gianyar and Tabanan [1]. Recorded in BPS statistics of Bali Province in 2012, Badung Regency was the district with the highest tourist visits in Bali, namely the number of visits of 2,892,019 people. Besides having tourist destination centers and excellence in terms of location, Badung Regency was also a market for main products for tourists, one of which is a restaurant. Based on the statistical data of the Bali Province Tourism Office in 2013, there were around 1,422 restaurant and eating places in the Badung Regency area [2].

Restaurants in Badung Regency provide various types of food for tourists. The prices offered are also very varied, ranging from cheap, medium to high prices. In addition, the increasing development of lifestyles also makes the development of restaurants more 
competitive. Restoration does not only become a regular place to eat, some restaurants also offer something special such as service, theme or special atmosphere to meet the needs of tourists.

Today, finding information about restaurants, especially in the Badung Regency area is quite easy, because there are already quite a lot of information systems or applications that provide information about restaurants. But the obstacle that is often experienced by tourists in using existing information systems or applications is that it is difficult to compare restaurants with one another in order to obtain the right restaurant based on the recommended one[3]. Not only tourists, some local residents also often feel confused in choosing the right restaurant to visit in Badung Regency based on information on the type of food, price, location, theme and service owned by the restaurant. In addition, if viewed from a geographical perspective, existing restaurants in Badung Regency it is also very difficult to find based on the address given. This is especially for tourists who have never traveled to Bali and don't know much about the areas in Bali.

Based on this description, we need a system that can provide choices and information in the form of spatial or interactive maps when choosing restaurants in Badung Regency. Therefore, the author took the title of the final assignment "Decision Support System Selection in Badung Regency with Geography Visualization". This decision support system will later use the Weighted Product method in comparing and determining recommended restaurants. The Weighted Product method is used because the choice of restaurants in Badung Regency can be classified into multi-objectives problems (many goals to be achieved) and multicriteria (many criteria to achieve goals). In addition, this method is also used so that tourists can determine the weight of the importance of each criterion, whether it is very important, important, important, or not important. In addition, this system will also be based on Geographic Information System (GIS) [4]. Geograpich Information System (GIS) is a computer-based information system, designed to work using data that has spatial information (spatial reference).

It is expected that with this system, it can provide convenience in comparing restaurants in Badung Regency so that it gets the right restaurant choice recommendations based on the restaurants compared, which corresponds to the weight values of each inputted criteria. In addition, this system is also expected to provide convenience when searching for restaurant locations by utilizing the Geographic Information System (GIS).

\section{METHODS}

Analysis of a system is very necessary to find out what processes are running on the system. The purpose of knowing these processes is to understand the nets of the system as a whole and the obstacles that may exist during system development.

At this stage what needs to be done is an analysis of the system to be built and knowing how the flow of data or information that will run in the system, which will be explored through problem analysis and system requirements analysis.

\subsection{State Of Te Art}

Research on geographic information systems about restaurants or culinary tourism has been discussed in previous studies [5] entitled "Designing Web-based Culinary Geographic Tourism Information System with Google API". In Dewanto's research on the geographic information system of culinary tourism whose case studies were conducted in Tasikmalaya area, it was only able to display culinary tourism in the form of markers on Google maps and provide information on culinary tourism in the form of culinary names, addresses, brief descriptions, menus and unit prices.

In addition, the same research was also discussed [6-7] entitled "Decision Support Systems for Culinary Tourism with Geographic Visualization". In Hamdani's research, it has

ACSIE Vol. 1, No. 1, May 2019: $11-20$ 
used a combination of decision support systems and geographic information systems. The decision support system in this study uses the rule of thumb method, with several comparative variables including the type of food, opening time, typical food, culinary location, budget, atmosphere or layout and restaurant facilities. This system is built on a desktop-based system that can only be run on a Windows operating system and uses Google Earth Professional installed on a computer that supports the existence of the system.

While in this study will combine the advantages of the two studies that have been carried out. Where in this study the system to be built will be web-based, with the hope that this system is more flexible and able to run well in different services by using the web browser. The system to be built in this study will also implement a decision support system that will be used to compare several restaurants using the Weighted Product (WP) method. The WP method is used so that users have the freedom to determine the comparison weight to determine restaurant choices. In addition, this system will also have a rating and review feature for restaurants, where users can provide values and opinions for restaurants in the system. The rating or review value will later be used as a comparison value for each restaurant. So the value of the comparable variables possessed by each retoran will be dynamic and up to data based on the values and opinions of the users. This system will also be visualized in the form of geography by utilizing the Google Map API to show the location of each restaurant registered in the system.

\subsection{Geographic Information System}

Manongga, et al. [8-9] publish their research in a journal entitled "Geographic Information System for Tourist Travel in the City of Semarang". Manongga, et al. shows that the Geographic Information System (GIS) is a computer-based information system which is a combination of elements of the map (geographical) and information about the map (attribute data), which is designed to obtain, process, manipulate, analyze, demonstrate and display spatial data to complete planning, processing and researching problems. Geographical Information Systems (GIS) are basically a combination of three main elements, namely: system, information and geography.

Geographic Information System (GIS) is an information system that emphasizes the element "geographic information". The term geographic information contains information about places located on the surface of the earth, and information about information (attributes) found on the surface of the earth whose position is given and known.

Computer systems for Geographic Information Systems (GIS) consist of hardware, software and procedures for compiling data input, processing, analyzing, modeling, and viewing geospatial data. Sources of geospatial data are digital maps, aerial photographs, satellite imagery, statistical tables and other related documents. Geospatial data is divided into graphical data (also called geometric data) and attribute data (thematic data). Graphic data has three elements: point (node), line (arc) and area (polygon) in the form of vector or raster which represent topology geometry, size, shape, position and direction.

In general, the Geographic Information System (GIS) process consists of three parts (subsystems), namely data input subsystems, data manipulation and analysis, and presenting data. Data input subsystem has the role of entering data and converting original data into forms that can be accepted and used in Geographic Information Systems (GIS). There are two kinds of geographic basic data, namely spatial data and attribute data. While the data manipulation and analysis subsystem serves to store, hoard, retract basic data and analyze data that has been stored on the computer. Data output subsystem serves to display geographic information as a result of data analysis in the Geographic Information System (GIS) process. The information is displayed in the form of maps, tables, charts, pictures, graphics and calculation results.

\section{3 Decision Support System}

Form According to Turban [10] Decision Support System (DSS) or Decision Support 
System (DSS) is a system that is able to provide problem solving and communication skills for problems with semi-structured and unstructured conditions. This system is used to assist decision making in semi-structured situations and unstructured situations, where no one knows for sure how decisions should be made.

SPK aims to provide information, guide, provide predictions and direct information users in order to make better decision making.

In general, Decision Support Systems are built by three major components, namely:

1. Database Management

An organized data subsystem in a database. Data which is a decision support system can come from outside or inside the environment. For SPK purposes, data that is relevant to the problems that are to be solved through simulation is needed.

2. Base Model

Is a model that represents the problem in a quantitative format (a mathematical model for example) as a basis for simulation or decision making, including objectives from problems (objectives), related components, constraints, and related matters others. The Base Model allows decision makers to analyze in full by developing and comparing alternative solutions.

3. Software System / User Interface

It is a combination of the two previous components, namely Database Management and the Base Model which are united in the third component (user interface), after previously presented in the form of a computer-understood model. The User Interface displays the system output for the user and receives input from the user into the Decision Support System.

\section{4 Weighted Produc Method (WPM)}

If the weighted product model (WPM) [11] is a decision-making method by multiplying it to connect the attribute rating, where the rating of each attribute must be raised first with the weight of the attribute in question [12]. WPM is a well-known multi-criteria decision analysis (MCDA) multi-criteria decision analysis or multi-criteria decision making method multi-criteria decision making (MCDM). This is similar to the weighted sum model (WSM) model. The main difference is that additions in the main mathematical operations now have multiplication. Like all MCDM / MCDA methods [13-14], what is given is a limited set of alternative decisions which are explained in terms of a number of decision criteria. Each decision alternative is compared to the other by multiplying a number of ratios, one for each decision criterion. Each ratio is lifted to power equal to the relative weight of the appropriate criteria.

WPM is often called dimensionless analysis because mathematical structures eliminate unit sizes. Therefore, WPM can be used in single and multi-dimensional MCDM / MCDM problems. That is, on the issue of decisions which alternatives are explained in terms that use different measurement units. The advantage of this method is that relative values can be used instead.

Briefly, the algorithm of this method will be explained as follows:

1. Multiplying all attributes for an alternative with the weight as a positive rank for the benefit attribute and the weight serves as a negative rank on the cost attribute

2. The multiplication results are summed to produce values for each alternative

3. Look for alternative values by doing the same steps as in step one, only using the highest value for each highest attribute for each benefit attribute and the lowest value for the cost attribute

4. Divide the value of $\mathrm{V}$ for each alternative with the standard value $(\mathrm{V}(\mathrm{A} *))$ that produces $\mathrm{R}$

5. Found the best alternative sequence that will be a decision.

ACSIE Vol. 1, No. 1, May 2019: $11-20$ 
An alternative approach with the WPM method is for decision makers to use new products without prior ratios. That is, to use the following variant of formula 1 given earlier:

$$
P\left(A_{K}\right)=\prod_{j=1}^{n}\left(a_{K j}\right)^{w_{j}}, \text { for } K=1,2,3, \ldots, m .
$$

In the previous expression the term $\mathrm{P}(\mathrm{AK})$ shows the total performance value (that is, not one relative) of an alternative AK when all of these criteria are considered to be together with the WPM model. Then, when the previous data is used, the exact rank comes from.

\section{5 Context Diagram}

The Context Diagram can illustrate the scope of restaurant selection decision support systems in Badung Regency with geographic visualization, as in Figure 1

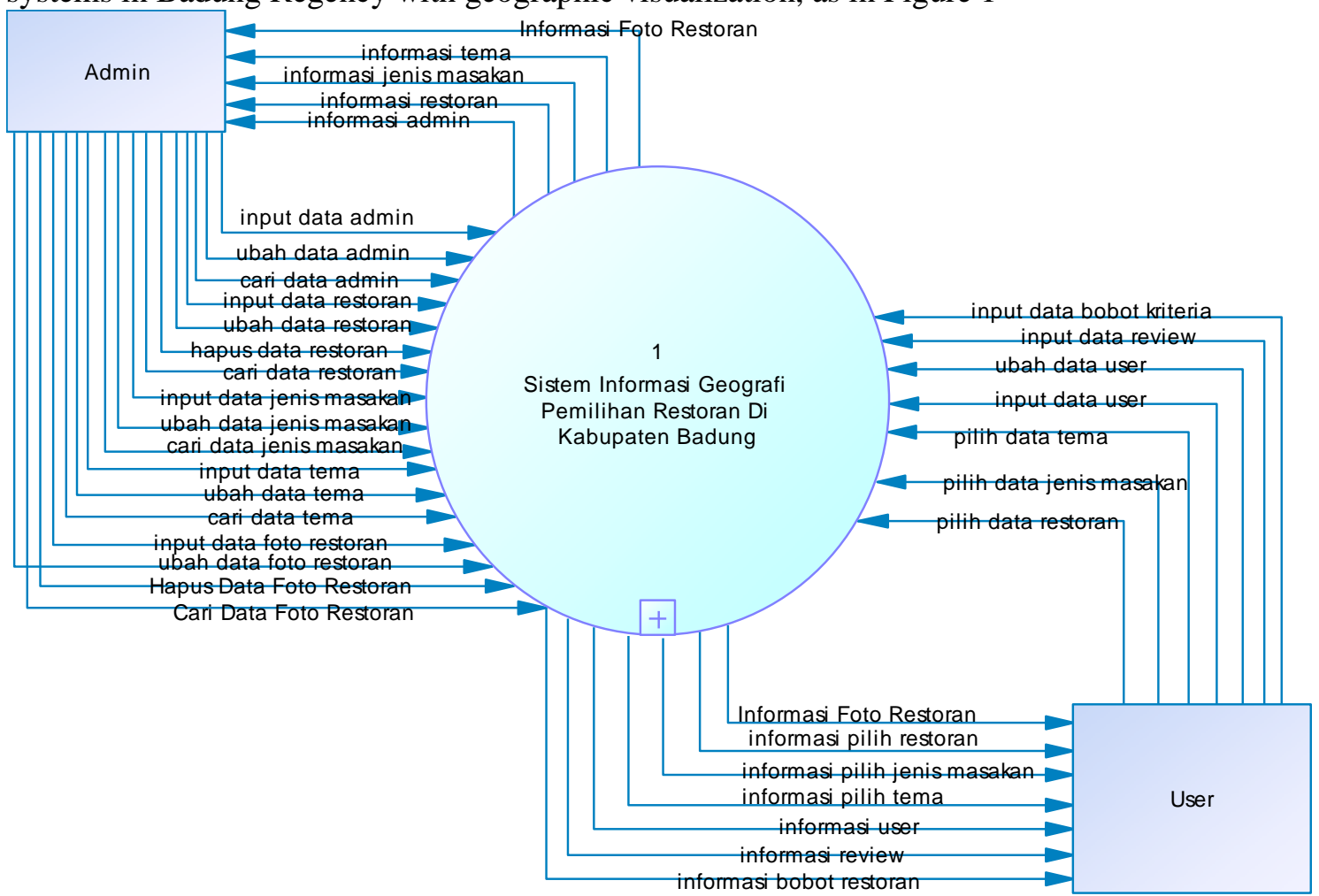

Figure 1 Context Diagram of Restaurant Selection Decision System in Badung Regency with Geography Visualization

\section{6 Data Flow Diagram (DFD)}

Data Flow Diagram (DFD) is a decomposition of the context diagram of restaurant selection decision support systems in Badung Regency with geographic visualization, which describes the entire process of data flow in this system[15-17]. This diagram can help understand the restaurant selection decision support system in Badung Regency with structured geographical visualization, as in Figure 2.

On level 0 DFD describes the overall process of data flow in restaurant selection decision support systems in Badung Regency with geographic visualization. Each process of data flow that exists in this system will be symbolized in detail. So that in general all data streams and processes in this system can be easily understood. 


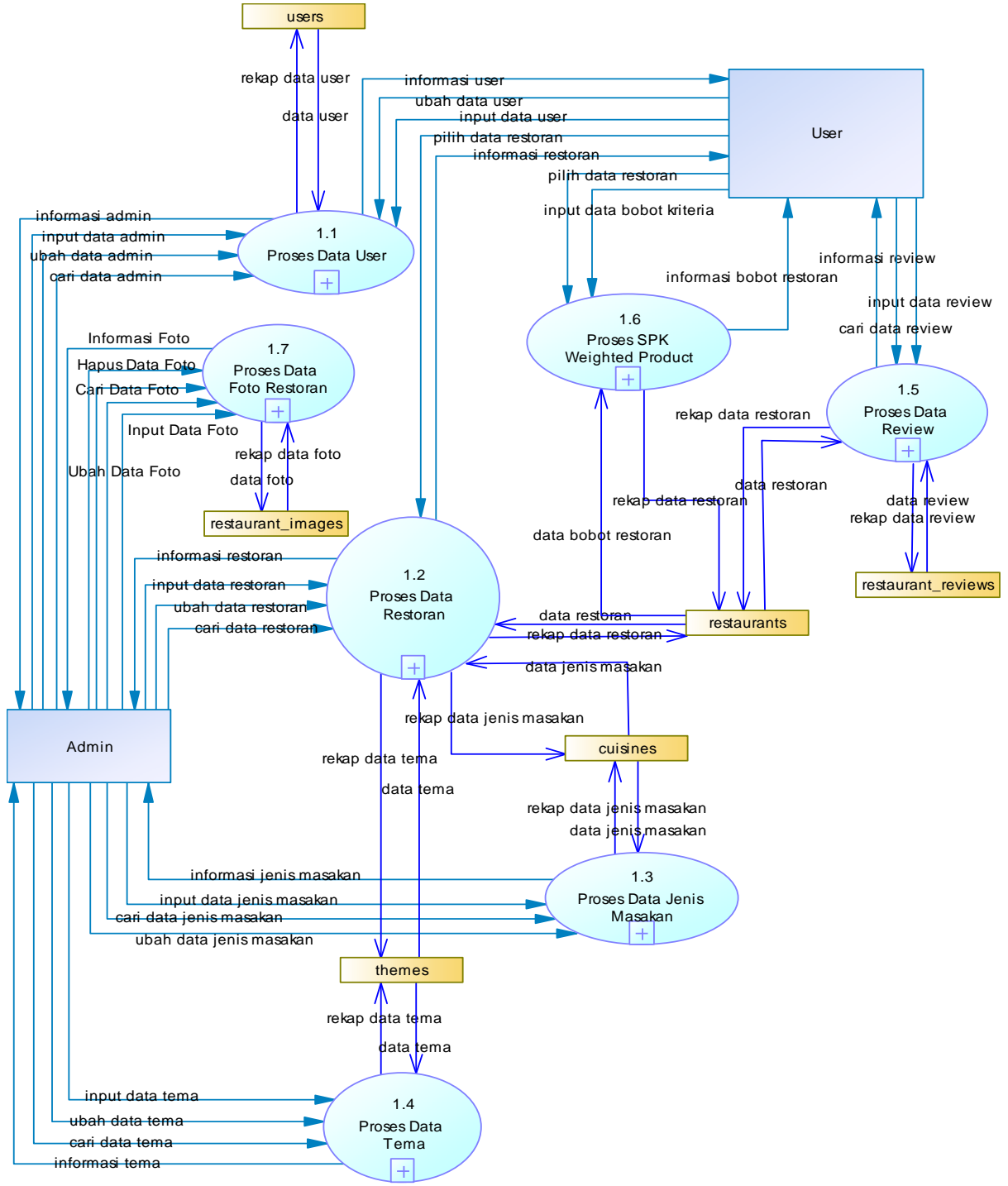

Figure 2 DFD level 0 Restaurant Selection Decision Support System in Badung Regency with Geography Visualization

\section{7 Calculation of Weighted Product Methods}

Below will be explained an example of manual calculation using the Weighted Product (WP) method in determining restaurant choices in Badung Regency based on the value of the weight given comparison, where in this example there are 3 restaurants that will be alternative choices, namely:

R1 : Made's Warung

R2 : Warisan Restaurant \& Bar

R3 : Gabah Restaurant \& Bar

The criteria used as a reference in the selection of restaurants in Badung Regency are 5, namely:

C1: Food Quality

C2: Food Prices

C3: Service

C4: Atmosphere

C5: Distance (m)

The level of importance for each food quality criterion is rated from 1 to 5 , namely:

ACSIE Vol. 1, No. 1, May 2019: 11-20 
$1=$ Very less,

$2=$ Less,

$3=$ Enough,

$4=$ Delicious,

$5=$ Very good

The level of importance for each criterion for food prices is also assessed from 1 to 5 , namely:

$1=$ Very cheap,

$2=$ Cheap,

$3=$ Medium,

4 = Expensive,

$5=$ Very expensive

The level of importance for each service criteria and atmosphere is assessed from 1 to 5 , namely:

$1=$ Very less,

$2=$ Less,

$3=$ Enough,

$4=$ High,

$5=$ Very high

Likewise, the level of importance for each distance criterion is also assessed from 1 to 5 , namely:

$1=$ Very close,

$2=$ Close,

$3=$ Medium,

$4=$ Remote,

$5=$ Very far away

The decision maker gives preference weights as:

$\mathrm{W}=(5,3,4,4,2)$

Criteria values from each alternative restaurant will be presented in the form of tables in table 3.4 below. For the criteria values $\mathrm{C} 1, \mathrm{C} 3$ and $\mathrm{C} 4$ in the table below, they will be taken from the rating values given by other users for each restaurant. And the $\mathrm{C} 5$ criterion value will be taken from the distance between users and these restaurants by utilizing Google Maps Distance Matrix. So the value of these criteria will be dynamic. As for the criteria value $\mathrm{C} 2$, it will be taken from the average value of the price range owned by the restaurant. The average value for $\mathrm{C} 2$ criteria is obtained by summing the lowest price and the highest price owned by the retoran then divided by 2 .

Table 1 Criteria Value

\begin{tabular}{|c|c|c|c|c|c|}
\hline \multirow{2}{*}{ Alternative } & \multicolumn{5}{|c|}{ Criteria } \\
\cline { 2 - 6 } & $\mathrm{C} 1$ & $\mathrm{C} 2$ & $\mathrm{C} 3$ & $\mathrm{C} 4$ & $\mathrm{C} 5$ \\
\hline $\mathrm{R} 1$ & 3.5 & 66.000 & 4 & 5 & 2.355 \\
\hline $\mathrm{R} 2$ & 4 & 90.000 & 3.5 & 4 & 1.421 \\
\hline $\mathrm{R} 3$ & 4 & 91.500 & 5 & 5 & 2.585 \\
\hline
\end{tabular}

There are 2 categories that distinguish the existing criteria, among others, as follows.

a. Criteria C1 (food quality), C3 (service) and C4 (atmosphere) are the profit criteria.

b. Criterion C2 (food price), C5 (restaurant distance) is the cost criterion.

Previously we have made weight repairs first, so that the total weight $\Sigma \mathrm{Wj}=1$ by: 


$$
\begin{aligned}
& \mathrm{W} 1=\frac{5}{5+3+4+4+2}=0,28 \\
& \mathrm{~W} 2=\frac{3}{5+3+4+4+2}=0,17 \\
& \mathrm{~W} 3=\frac{4}{5+3+4+4+2}=0,22 \\
& \mathrm{~W} 4=\frac{4}{5+3+4+4+2}=0,22 \\
& \mathrm{~W} 5=\frac{2}{5+3+4+4+2}=0,11
\end{aligned}
$$

Then determine the Vector $\mathrm{S}$ value where each criterion value will be raised with the prefixed weight weight. For criteria categorized into cost criteria, namely price criteria and distance criteria, the ranks owned will be minus (-). The value of the $\mathrm{S}$ vector can be calculated as follows:

$$
\begin{aligned}
& \text { S1 }=\left(3,5^{0,28}\right)\left(66.000^{-0,17}\right)\left(4^{0,22}\right)\left(5^{0,22}\right)\left(2.355^{-0,11}\right)=0.177143 \\
& \text { S2 }=\left(4^{0,28}\right)\left(90.000^{-0,17}\right)\left(3,5^{0,22}\right)\left(4^{0,22}\right)\left(1.421^{-0,11}\right)=0.170498 \\
& \text { S3 }=\left(4^{0,28}\right)\left(91.500^{-0,17}\right)\left(5^{0,22}\right)\left(5^{0,22}\right)\left(2.585^{-0,11}\right)=0.180847
\end{aligned}
$$

Determine the vector value to be used Calculating Preferences (Vi) for ranking:

$$
\begin{aligned}
& \mathrm{V} 1=\frac{0.177143}{0.177143+0.170498+0.180847}=0.335189 \\
& \mathrm{~V} 2=\frac{0.170498}{0.177143+0.170498+0.180847}=0.322614 \\
& \mathrm{~V} 3=\frac{0.180847}{0.177143+0.170498+0.180847}=0.342197
\end{aligned}
$$

The V3 value shows the biggest value so in other words V3 is the best alternative choice, Gabah Restaurant \& Bar is the best choice for restaurants according to the weight given by decision makers.

\section{RESULTS AND DISCUSSION}

System implementation is the application stage of system analysis and design that has been done before. This system was developed, developed using the programming language PHP and MYSQL as a database. The developer needs that the system can be applied, namely builder software, builder hardware and webhosting needs.

\subsection{The front page of the system}

The front page of the system is the main page for users. At the top there is a head piece with a logo and polaroid image.

Under the header a search form is provided based on the name of the restaurant, type of cuisine and restaurant theme. This search form is used to filter restaurants according to the input value entered. Under the search form there is a map containing points of location of the restaurant and location of the user. If the user clicks on one of these points, information about the restaurant will appear from that point. After the map, several restaurants will be randomly displayed with comparable values. The appearance of the front page of the system can be seen in Figure 3.

\subsection{System Weighting Page}

To compare restaurants, users must filter by type of cuisine first. After that, there will be restaurants that can be compared, namely restaurants that have a checkbox at the top right

ACSIE Vol. 1, No. 1, May 2019: $11-20$ 
corner. Users can choose a maximum of 20 restaurants to compare. When the user has selected more than 1 restaurant the Compare button will appear on the screen in the lower right corner. And the user can give the comparison weight by pressing the Compare button. The appearance of the restaurant selection page for comparison can be seen as follows.

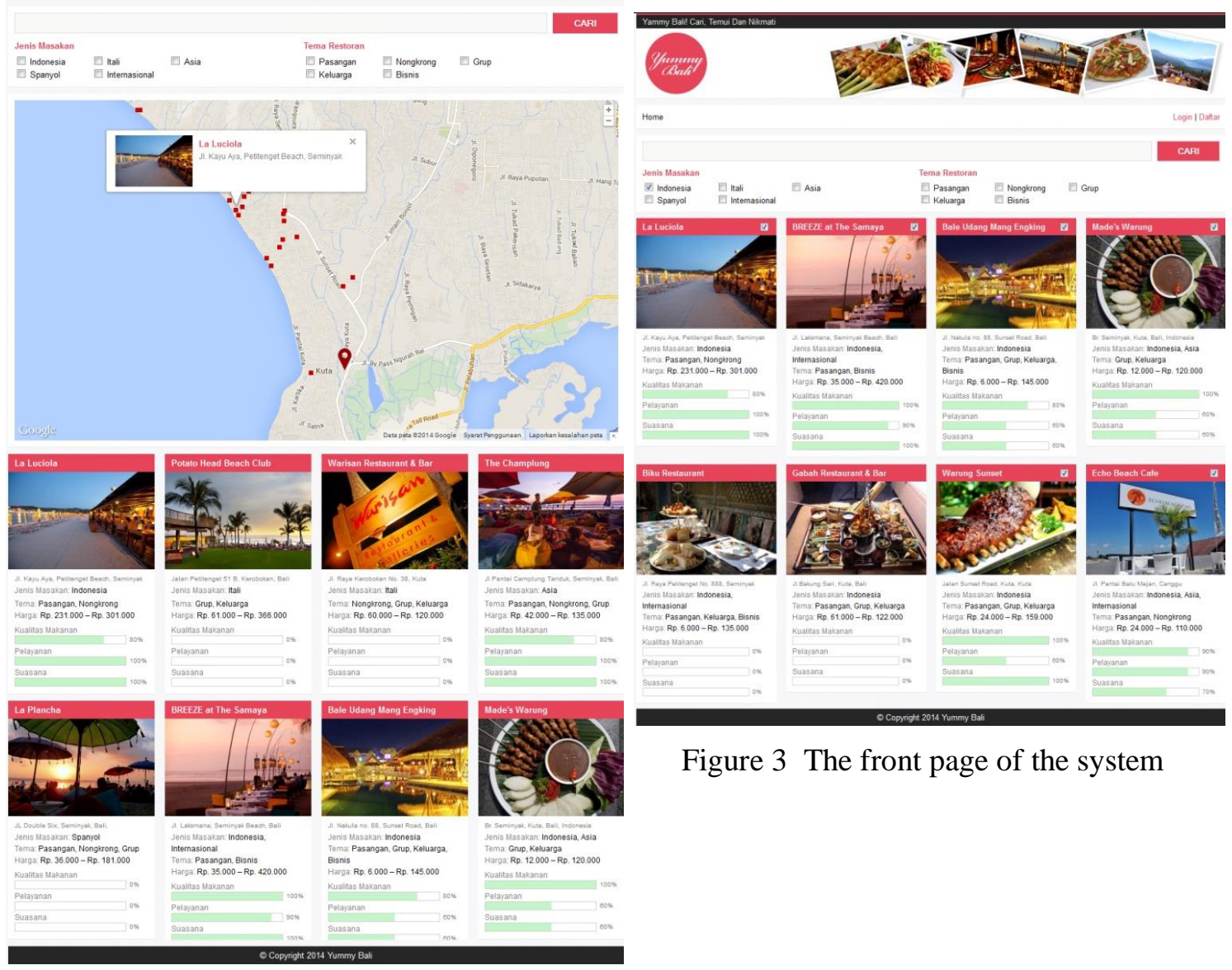

Figure 4 Reataurant Selection Page for Comparison

\section{CONCLUSION}

Based on the analysis of the discussion in the entire chapter on the final assignment entitled "Decision Support System for Restaurant Selection in Badung Regency with Geographic Visualization", it can be summarized as follows.

Decision Support System for Choosing Restaurants in Badung Regency with Geographic Visualization has been built with several stages, namely analysis of the system starting from problem analysis, needs analysis, data collection and data analysis. After that proceed with the system design process that uses structured design that is by using Data Flow Diagrams (DFD), database design with Entity Relationship Diagram (ERD) and interface design as the basis of the display system that has been made. In the implementation phase, this system is built using php and mysql programming languages as a database. Then at the testing stage, the system has been tested using the black box method and gives the results that the system has been built according to the design carried out.

Functionally the development of the system is appropriate. The system that is built has worked well and can produce output in accordance with what is expected. The results of restaurant ranking generated between manual testing and testing with the system have also 
ISSN (print): $\mathrm{xxxx}-\mathrm{xxxx}, \mathrm{ISSN}$ (online): $\mathrm{xxxx}-\mathrm{xxxx}$

produced the same ranking sequence. From these results it has been shown that the weighted product method has been successfully implemented on the system.

The system is feasible to be used to assist users in comparing restaurants in Badung Regency to get recommended restaurant sequences according to the weight of criteria entered by the user.

The system has been able to assist users in knowing the location of restaurants by utilizing Google Map.

\section{SUGGESTION}

At the writing of this final project report, of course there are still shortcomings that can be refined again in the next study. In order for this application to be better, the suggestions that can be used are:

1. The design of this system is made responsive, so that it can adjust the size of the device from the user who uses it. Like users who use tablets or smartphones.

2. Can be developed on a system that has been made for example adding new features such as users forgetting passwords.

3. Interface / Interface on the system is made more attractive so that it does not feel bored in the use of this system.

\section{REFERENCES}

[1] Arief, Abd. Rachman. 2005. Pengantar Perhotelan dan Restoran.Yogyakarta : Graha Ilmu.

[2] Basyaib, Fachmi. 2006. Teori Pembuatan Keputusan. Jakarta : Grasindo.

[3] Dewanto. 2012.Rancang Bangun Sistem Informasi Geografis Wisata Kuliner berbasis Web dengan Google API.

[4] Elian,Alqod., Mazharuddin, Ary., Studiawan, Hudan. 2012. "Layanan Informasi Kereta Api Menggunakan GPS, Google Maps, dan Android". Jurnal Teknik Pomits 1, 1:1-6.

[5] Goodman, R.J.Jr. 2002.F\&B Service Management, Edisi kedua. Jakarta:Erlangga.

[6] Hamdani. 2010. "Sistem Pendukung Keputusan Wisata Kuliner Dengan Visualisasi Geografi”. Jurnal Informatika Mulawarman, 5:19-26.

[7] Jogiyanto, Hartono. 2005. Analisis dan Desain Sistem Informasi, Edisi III. Yogyakarta: Andi.

[8] Komputer, Wahana. 2011. Matering CMS Programming with PHP \& MYSQL. Yogyakarta: Andi.

[9] Komputer, Wahana. 2006. Membuat Website Interaktif Dengan Macromedia Dreamweaver MX. Yogyakarta: Andi.

[10] Ladjamudin, Al-Bahra bin. 2005. Analisis dan Desain Sistem Informasi. Yogyakarta : Graha Ilmu.

[11] Marsum W.A. 2007. Restoran dan Segala Permasalahannya. Yogyakarta : Andi.

[12] Manongga, Danny., Papilaya, Samuel., PandieSelfiana. 2009. "Sistem Informasi Geografi Untuk Perjalanan Wisata Di Kota Semarang”. Jurnal Informatika 10, 1:1-9.

[13] Nugroho, Bunafit. 2008. Latihan Membuat Aplikasi Web PHP dan Mysql dengan Dreamwaver. Yogyakarta : Gava Media.

[14] Riadi, Muchlisim. 2013. Sistem Pendukung Keputusan (SPK). <URL: http://www.kajianpustaka.com/2013/09/sistem-pendukung-keputusan-spk.html>.

[15] Rosa, A.S. dan Shalahuddin, M. 2013. Rekayasa Perangkat Lunak Terstruktur dan Berorientasi Objek. Bandung :Informatika Bandung.

[16] Sidik, Betha dan Pohan, Husni I.2009.Pemrograman Web Dengan HTML. Bandung : Informatika.

[17] Suastuti, Ni Luh. 2011.Faktor-Faktor Yang Mempengaruhi Wisatawan Terhadap Produk Freestanding Restaurant Di Kawasan Pariwisata Nusa Dua - Kabupaten Badung. 